\title{
PERIPHERAL FRAGMENTS: DISLOCATION AS ELLIPSIS
}

\author{
DENNIS OTT \\ UNIVERSITY OF GRONINGEN
}

\section{INTRODUCTION}

In this paper, I argue for a unified analysis of Contrastive Left-dislocation (CLD) and Rightdislocation (RD) in Germanic. Examples of the two constructions are given below:

Contrastive Left-dislocation

a. Den Peter, den kenne ich. (GE)

the.ACC Peter him.ACC know I

b. Gisteren, toen heeft Jan dat boek terug gebracht. (DU)

yesterday then has John that book back brought

Right-dislocation

a. Den kenne ich, den Peter. (GE)

him know I the Peter

b. Tasman heeft ze gezien, die Maoris. (DU)

Tasman has them seen those Maoris

I will henceforth refer to the dislocated XP, printed boldface above, as the $d X P$, to the clause it precedes or follows as the host clause, and to the correlative element inside the host clause (underlined above) as the anchor.

Schematically and pre-theoretically, the two constructions can be summarized as follows:

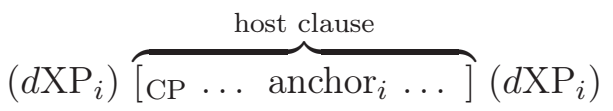

CLD has been extensively studied in the literature (see the references in Alexiadou 2006), while comparatively little attention has been devoted to RD. ${ }^{1}$ In what follows, I will first present the theoretical problem posed by CLD and RD and then provide a principled solution based on the idea that the $d \mathrm{XP}$ in either case is the surface remnant of clausal ellipsis.

\section{Theoretical Challenges}

The main theoretical problem posed by both CLD and RD is the Janus-faced nature of the $d \mathrm{XP}$ in both constructions:

- On the one hand, the dXP has certain properties that strongly suggest that it is not within the sentential domain of the host clause.

- On the other hand, the $d \mathrm{XP}$ shows connectivity into the host clause, indicating that it is an integral part of that sentential domain.

For questions, comments, and suggestions I thank Werner Frey, Erich Groat, Jason Merchant, Hubert Truckenbrodt, Mark de Vries, and Jan-Wouter Zwart. For details of the approach sketched here, see Ott $2011,2012$. Abbreviations used: DU $=$ Dutch, GE = German, IC = Icelandic, NO = Norwegian.

${ }^{1}$ But see, for instance, Altmann 1981, Zwart 2001, Averintseva-Klisch 2008, de Vries 2009, and Truckenbrodt forthcoming; the latter work converges in several respects with the present approach. 
Let us first consider evidence in favor of the idea that the $d \mathrm{XP}$ derivationally originates inside the host clause. First, we note that $d \mathrm{XP}$ and anchor obligatorily agree in case:
a. Pessum hring, honum hefur Ólafur lofað Maríu. (IC) this.DAT ring it.DAT has Olaf promised Marí
b. Ég pekki hana ekkert, dóttur hans.
I know her.ACC nothing daughter.ACC his

Furthermore, the $d \mathrm{XP}$ reconstructs. As shown below, an element of the $d \mathrm{XP}$ can be bound by material inside the host clause:

(5) a. Seinen $_{i}$ besten Freund, den sollte jeder $i$ gut behandeln. (GE)

his best friend him should everyone well treat

b. ${ }^{*}$ Anneke $_{i}$ d'r broer, die geloof ik dat $z_{i}$ wel aardig vindt. (DU) Anneke's brother him believe I that she sort of nice finds

a. $\operatorname{Jan}_{i}$ zag iemand in de spiegel: zichzelf ${ }_{i}$ (DU)

Jan saw someone in the mirror himself

b. ${ }^{*} \mathrm{Sie}_{i}$ hat ihn mit einer Anderen gesehen, Marias ${ }_{i}$ Freund. (GE) she has him with a.FEM different seen Maria's boyfriend

Facts like these have motivated movement analyses of CLD, dating back to Vat 1981.

At the same time, however, it is straightforward to establish that the $d \mathrm{XP}$ is not an integral part of the host clause. The latter is always syntactically complete on its own; in the case of CLD this yields an apparent verb-third pattern. Within standard models of clause structure and $\theta$-roles, there is simply 'no room' for the $d \mathrm{XP}$ in either CLD and RD.

There is further evidence for the externality of the $d \mathrm{XP}$. First, interjections / particles can intervene between $d \mathrm{XP}$ and host clause:
a. $\mathrm{Zijn}_{i}$ moeder, god, die haat iedere $\operatorname{puber}_{i}$. (DU)
his mother God her hates every teenager
b. Ich habe heute jemanden getroffen, ja, (nämlich) den Peter. (GE) I have today someone.ACC met yes namely the.ACC Peter

Second, the category of the $d \mathrm{XP}$ need not match that of a host-internal trace (where present), as witnessed in cases of P-stranding under R-pronoun movement in the host clause:

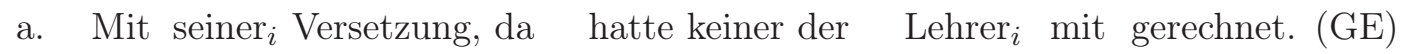
with his relocation there had none of the teachers with reckoned

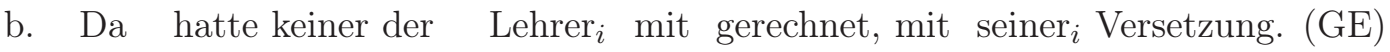
there had none of the teachers with reckoned with his relocation

We have arrived at a dilemma: the $d \mathrm{XP}$ appears to be simultaneously external and internal to the host clause. I now present an analysis that resolves the apparent paradox.

\section{Dislocation subdued}

I propose that both CLD and RD involve underlyingly biclausal structures, in which two parallel clauses are juxtaposed. Parallelism of the two clauses enables ellipsis in either one, ${ }^{2}$ phonetically reducing one of the two clauses to an XP that has moved to its edge (= the $d \mathrm{XP}$ ); I follow Merchant 2001 and others in taking this reduction to be PF-deletion.

\footnotetext{
${ }^{2}$ I cannot go into details of the theory of ellipsis parallelism here for reasons of space; the reader is referred to Merchant 2001 for discussion.
} 
Turning first to RD, I propose to analyze an example like (2-a) as follows:

a. $\left[\mathrm{CP}_{1}\right.$ den kenne ich $]\left[\mathrm{CP}_{2}\right.$ den Peter $_{i}\left[\right.$ kenne ich $\left.\left.t_{i}\right]\right] \rightarrow$ PF-deletion

b. $\left[\mathrm{CP}_{1}\right.$ den kenne ich $]\left[\mathrm{CP}_{2}\right.$ den Peter $_{i}\left[\right.$ thent $\left.\left.t_{i}\right]\right]$

The $d \mathrm{XP}$ has undergone $\overline{\mathrm{A}}$-movement to the edge of $\mathrm{CP}_{1}$; clausal ellipsis at $\mathrm{PF}$ reduces the redundant $\mathrm{CP}_{2}$ up to the $d \mathrm{XP}$. Importantly, this type of ellipsis (typically taken to be deletion of IP, but see Ott in progress) is independently attested in a wide range of constructions, such as sluicing (Merchant 2001), fragment answers (Merchant 2004), split questions (Arregi 2010), and others.

Conversely, CLD is derived by clausal juxtaposition and backward ellipsis in $\mathrm{CP}_{1}$ :

a. $\left[\mathrm{CP}_{1}\right.$ den Peter $_{i}\left[\right.$ kenne ich $\left.\left.t_{i}\right]\right]\left[\mathrm{CP}_{2}\right.$ den kenne ich $] \rightarrow$ PF-deletion

b. $\left[\mathrm{CP}_{1}\right.$ den $\left.\operatorname{Peter}_{i}\left[t_{\imath}\right]\right]\left[\mathrm{CP}_{2}\right.$ den kenne ich $]$

$(=(1-\mathrm{a}))$

Such backward ellipsis is independently attested, for instance in backward sluicing ( I don't know what $\Delta$, but John will have something). Notice that unlike both movement and base-generation approaches to CLD, the analysis in (10) avoids a syntactic verb-third structure: V3 arises only at the surface, as a result of PF-deletion.

The ellipsis analysis enables us to cut the Gordian knot: the dXP is now both external and internal to the host clause. It is external in that it is the surface remnant of a separate CP; this allows for intervening material as in (7) above, and for the categorial 'mismatch' witnessed in (8):

$$
\begin{aligned}
& {\left[\mathrm{CP}_{1}[\mathrm{PP} \text { mit seiner Versetzung }]_{i}\right. \text { ] }} \\
& {\left[\mathrm{CP}_{2} \mathrm{da}_{k} \text { hatte keiner der Lehrer mit } t_{k} \text { gerechnet }\right](=(8-\mathrm{a}))}
\end{aligned}
$$

At the same time, the analysis predicts connectivity effects. Since the reduced clause is necessarily parallel to the host clause, both will contain identical case-assigners, and hence $d \mathrm{XP}$ and anchor are case-marked 'in parallel' (compare Merchant's 2001; 2004 reasoning for sluicing/fragment answers).

Leftward $\overline{\mathrm{A}}$-movement internally to the reduced clause will induce reconstruction effects of the usual kind, yielding the net effect of reconstruction into the host clause - really, reconstruction internally to the elliptical clause:

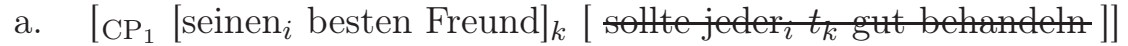
$(=(5-\mathrm{a}))$
b. $*\left[\mathrm{CP}_{2}\left[\text { Marias }_{i} \text { Freund }\right]_{k} \mid\right.$

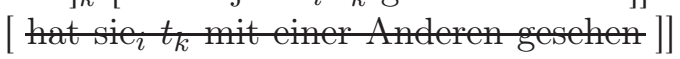$$
(=(6-\mathrm{b}))
$$

Reconstruction to trace position yields the observed binding/Condition C effects. No special assumptions are necessary; the $d \mathrm{XP}$ reconstructs in a perfectly ordinary fashion.

There is further evidence for the movement-cum-deletion approach. Just like in sluicing (Merchant's 2001 second Form-identity Generalization), the dXP in dislocation reflects the (im-)possibility of P-stranding in a given language. Consider first CLD:

$\{*($ Mit $)\}$ meiner Schwester, mit der habe ich mich oft gestritten. (GE) with my sister with her have I REFL often quarreled
a. (??Med) søstera mi, ho krangla jeg ofte med. (NO) with sister my her quarreled I often with
b. (?? Um) mömmu sína $i$, hana talar hver einasti unglingur ${ }_{i}$ illa um. (IC) about mother his.ACC her.ACC talks each single youngster badly about

This discrepancy is expected on the present analysis: being a P-stranding language, the preposition is stranded inside the ellipsis site in $\mathrm{NO} / \mathrm{IC}$ :

$$
\left[\mathrm{CP}[\mathrm{s} \emptyset \mathrm{stera} \mathrm{mi}]_{i}[\text { tangla jeg }\right.
$$


Since GE does not permit P-stranding in the relevant contexts, no such stranding is possible, and consequently the preposition is retained. As expected, the exact same contrast is found in RD:

Ich habe den ganzen Tag auf ihn gewartet, *(auf) den Peter. (GE)

$I$ have the whole day for him waited for the Peter

a. Har du snakka med døm ennå, (?? med) ungene? (NO) have you spoken with them yet with kids.DEF

b. Jón talaði við hana, (?? við) gömul konuna. (IC) Jon talked to her to old lady.DEF

The analysis thus provides an elegant way out of the dilemma we arrived at in section 2, and makes welcome predictions wrt. P-stranding. See Ott 2011, 2012 for many further arguments corroborating the ellipsis analysis of dislocation.

\section{Conclusion}

Dislocation constructions reduce to juxtaposition of clauses and sluicing-type clausal ellipsis in either one, as schematically summarized below:

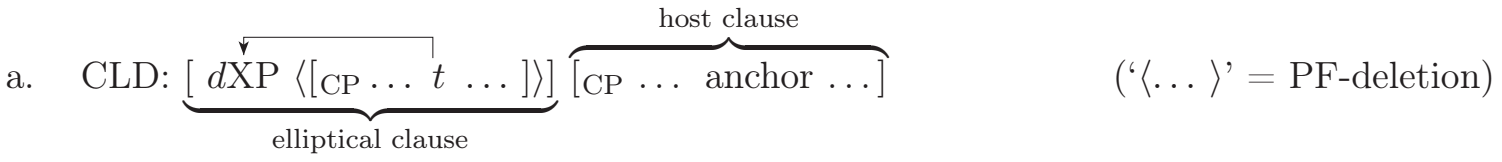

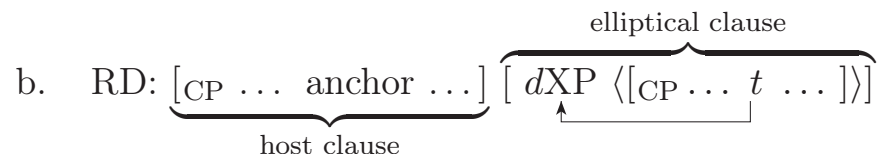

This approach reconciles properties of the $d \mathrm{XP}$ indicating that it is part of the sentential domain of the host clause (by placing it within the sentential domain of a parallel clause) with those betraying its externality to the host clause. No special mechanisms are required to derive the 'dislocation' surface pattern, and constructional residue is eliminated from the theory of UG.

\section{REFERENCES}

Alexiadou, Artemis. 2006. Left-dislocation (including CLLD). In The Blackwell companion to syntax, ed. Martin Everaert and Henk van Riemsdijk, 668-699. Oxford: Blackwell.

Altmann, Hans. 1981. Formen der 'Herausstellung' im Deutschen: Rechtsversetzung, Linksversetzung, Freies Thema und verwandte Konstruktionen, volume 106 of Linguistische Arbeiten. Tübingen: Niemeyer.

Arregi, Karlos. 2010. Ellipsis in split questions. Natural Language E Linguistic Theory 28:539-592.

Averintseva-Klisch, Maria. 2008. Rechte Satzperipherie im Diskurs: Die NP-Rechtsversetzung im Deutschen. Doctoral Dissertation, University of Tübingen.

Merchant, Jason. 2001. The syntax of silence. Sluicing, islands, and the theory of ellipsis, volume 1 of Oxford Studies in Theoretical Linguistics. Oxford: Oxford University Press.

Merchant, Jason. 2004. Fragments and ellipsis. Linguistics \& Philosophy 27:661-738.

Ott, Dennis. 2011. An ellipsis approach to Contrastive Left-dislocation. Ms., University of Groningen (lingBuzz/001415).

Ott, Dennis. 2012. Right-dislocation as deletion. Ms., University of Groningen.

Ott, Dennis. in progress. Generalized sluicing. Ms., University of Groningen.

Truckenbrodt, Hubert. forthcoming. On the prosody and syntax of right dislocation, adjunct postposing, and sentential pro-forms in German. In Inner-sentential propositional pro-forms (working title), ed. Werner Frey, André Meinunger, and Kerstin Schwabe. Amsterdam: John Benjamins.

Vat, Jan. 1981. Left dislocation, connectedness, and reconstruction. Groninger Arbeiten zur germanistischen Linguistik 20:80-103.

de Vries, Mark. 2009. The left and right periphery in Dutch. The Linguistic Review 26:291-327.

Zwart, Jan-Wouter. 2001. Backgrounding ('right-dislocation') in Dutch. Ms., University of Groningen (available at http://www.let.rug.nl/ zwart/docs/backgr.pdf). 